\title{
Institutional Framework of the Economy against Corruption in Georgia
}

\author{
Tsotne Zhghenti
}

\begin{abstract}
Corruption is one of the most actual problem of the public economic policy which is mostly described as evil phenomena. But what are foundations of corruption? Is it a separate problem or reflection of other problems of the economy? Is corruption a result or a reason of economic processes? In this paper we describe how corruption is determined by institutional framework of the economy. Characteristics of formal and informal institutions are inception of corrupted processes. We will analyze institutional foundations of corruption, Georgian escaping story from corrupted economy and compare countries institutional framework against corruption.
\end{abstract}

Index Terms-Corruption, institutions, institutional foundations of corruption, Georgian economy.

\section{INTRODUCTION}

As many other developing or transition country, corruption was a part of daily economic life in Georgia and in other soviet republics. Not only first years of transition, also state policy in post-transition phase were characterized by high rates of corruption in Georgia. These problems had institutional foundations formed in the planned economy and then transformed in the market economy. Before analyzing history of corruption foundations review its theoretical foundations.

Corruption is an economic situation which is vitally for both parties. Why individuals and firms prefer to coordinate bypass the legal framework? One of the First researcher who focused on corruption problems in the economics science Susan Rose-Ackerman also emphasizes importance of institutional framework: "Corruption arises from problems with the underlying institutional structures of state and of society, and that is where policy must be directed" [1], [2].

According to neoclassical theory, individuals have rational preferences to maximize their utilities. For maximizing their benefits, individuals have choices: work formal or work informal. To make a decision they compare costs (including alternative costs and risks). Motivation of the side of state representatives is easily understood, they can earn more revenue from corruption if there are less risks for sanctions. For non-state side important part of total costs are transaction costs, which is caused by formal institutional structure. Concept of transaction costs is developed by Ronald Coase Markets are institutions that exist to facilitate exchange, that is, they exist in order to reduce the cost of carrying out

Manuscript received May 20, 2017; revised July 23, 2017.

Tsotne Zhghenti is with Ivane Javakhishvili Tbilisi State University, Georgia (e-mail: tsotne32@gmail.com). exchange transactions. In an economic theory which assumes that transaction costs are nonexistent. Markets have no function to perform, and it seems perfectly reasonable to develop the theory of exchange [3]. According to Train Eggertsson, transactions costs are the costs that arise when individuals exchange ownership rights to economic assets and enforce their exclusive rights [4].

Major purpose of institutions is to lower uncertainty, so state institutions must simplify processes between individuals, firms and government. But in practice, many of state institutions are increasing uncertainty by creating institutional barriers. Complicated institutional structure also increases transaction costs (like time, money for preparing documents, information imperfection...). In the Economy with weak institutional framework individuals prefer to get out from the legal framework to avoid unnecessary expenditures.

To analyze institutional foundations of corruption in post-communist economies it is better to review them separately by formal and informal institutions because different institutions have different characteristics. This is the most popular distinction between institutions. Informal institutions defined by codes of conduct, norms of behavior and conventions. They come from socially transmitted information and are a part of heritage that we call a culture. Unlike informal one, formal institutions are written; they include political (and judicial) rules, from constitutions, to statue and common laws, to specific bylaws, and finally to individual contracts defines constraints, from general rules to particular specifications [5].

New institutional economic school describe every operations in the planned economy with market economy rules. Society, member of central party, farmers, organizations and individuals have own interests to maximize their (their member's) wealth [6]. Foundations of corruption in Soviet Union is given below:

Informal foundations - Soviet Union was a planned economy, where state must had a power to manage all economic processes. But in the reality, practice shows that total control is unable. The new soviet man is a dedicated public servant who would never pursue private gain to society's detriment [7]. From neoclassical economic theory, we know that people are welfare maximizing persons and it's true in every social-political systems and also for all members of the economic processes in the planned economy In the Soviet Union, people had not alternatives to maximize their wealth; there were no alternative jobs, no choices to be entrepreneur and no private business. One and the only way for increasing income was to bribe state wealth, which was identified as wealth of whole population, but also as a wealth with no owner. Lots of corruption mechanisms were formed 
in this period and they stayed alive in the market economy. Corruption was a habit for people and it was described as "Easiest way to make your business".

Formal foundations - For transition country most of legislation is created by duplicating from developed countries, also political rent is important factor of forming laws. Flaws in laws, in government structure and in policy making mechanisms are causing demand and motivation of corruption. In Georgia, complicated institutional structure was contributing high levels of corruption. Structure of enterprises were formed in planned economy, so they were ineffective for positioning on the market. Most of them were unsuccessful without government subsidies.

\section{GEORGIAN ESCAPING STORY FROM CORRUPTED ECONOMY}

In 2004, Georgia was one of the most corrupted country in the world - 130th in 160 economy by less corrupted rankings (Corruption Perceptions Index 2004, Transparency International). In 2016, after years of successful anti-corruption reforms and institutional development it is among less corrupted countries - 44th place in 176 economy (Corruption Perceptions Index 2016, Transparency International). In general, it must be said that changes in informal institutions is a long-run process. Public opinion about role of the state in economic processes are changing slowly. Society also slowly adopt new legal ways how to increase their welfare and to be successful. In Georgia, direct fight from government to corruption was a hard instrument in short term. But in the long- run we must look at institutional level, where most successful reforms were decreasing regulations and to streamline of institutional structure. Institutions which cause uncertainty could cause also corruption during overcoming from uncertainty. Reforms were carried out in many sectors, but we highlight some reforms linked to institutional structure.

To reduce motivation size of corruption one way is to reduce size of state, because corruption is a state phenomenon. Another way is to improve institutional structure by reducing stimulus to go illegal and best stimulus are size of costs as we mentioned above.

In our research we will speak about Policies that reduce transaction costs for business.

Important determinant to choose work in formal or informal besides the tax rates are other costs to prepare, file and pay taxes. After reforms in taxation codex in 2006, number of taxes were decreased from 21 to 6 for simplify taxation process in Georgia ( 5 state tax: income tax, corporate tax, VAT, taxes on imported goods, excise; 1 local tax: property tax). Total tax rate is $16.5 \%$ of commercial profits which is less than other upper middle income countries 41.4\% (The World Bank, 2016). Through institutional side, advantage of the taxation policy is that it is simple, only 8 payments in a year. But it needs 270 hours per year to prepare and pay taxes. This indicator is decreased from 448 hours in 2005 but still worse compare to European Union countries average 176 hours (Doing business 2016, The World Bank).

In many cases for bossiness and for especially for foreign investors other than tax rate more important factor is cost to prepare taxes. Because everyone want avoid court cases and uncertainty in their firms and have a clear picture to forecast future.

Major reforms were carried out about simplify other state services, which are main source of corruption. To avoid transactions costs (mostly time) for preparing some documents bribe was a best way. According to doing business index Georgia today is 3th country in the world by easy registering property and 8th country to start business Doing business 2016, The World Bank).

Important contributing factor for reducing transaction costs and eliminating corruption is use of e-services.

Some policies that reduced size of the state had also influence on other private sectors. Moving from planned to market economy, fast and complete privatization process is one of the most important condition, because government enterprises are good channels for corruption and most of them are working with negative profits. Replace owners from state to private diminishes corruption in the enterprise, EBRD transformation indicator "Large scale Privatization" went from 3.3 to 4.0 in 2004-2007 years. Score 4.0 means that more than half of state-owned enterprises are in private ownership with corporate governance of these enterprises (Transition Indicators, EBRD, 2016).

According to 2015-2016 Corruption Barometer, only 12\% of Georgians include corruption at three biggest problem facing the country. But $41 \%$ rates government actions to fight against corruption badly (2015-2016 Corruption Barometer, Transparency International). Its means that corruption is eliminating through improving institutional structure of country and not only current state policies against it. People have trust in institutions and have less motivation to use corruption ways in their business.

\section{PRACTICAL PART}

How smart institutional structure for business making affect on corruption perceptions? Is it working in the real world? We must compare variables which can describe characteristics institutional barriers for business making process.

One of the best suitable indicator to determine institutional framework for business are doing business indexes given by World Bank. The Doing Business project provides objective measures of business regulations and their enforcement across 190 economies and selected cities at the subnational and regional level (About Doing Business, Doing Business 2017). Doing Business includes following components:

- Paying Taxes

- Trading across Borders

- Getting Electricity

- Protecting Minority Investors

- Dealing with Construction Permits

- Getting Credit, Resolving Insolvency

- Starting a Business, Enforcing Contracts

- Registering Property

Level of corruption can be measured by corruption perception index from Transparency International. On anti-corruption glossary corruption is described as "Generally 
speaking as "the abuse of entrusted power for private gain". Corruption can be classified as grand, petty and political, depending on the amounts of money lost and the sector where it occurs". The Corruption Perceptions Index aggregates data from a number of different sources that provide perceptions of business people and country experts of the level of corruption in the public sector. Data is scaled of $0-100$ where a 0 equals the highest level of perceived corruption and 100 equals the lowest level of perceived corruption (Transparency International). A major problem with this index is that it rely on perceptions [8]. But, perceptions really affect on informal institutional framework. Institutions affect development both directly and indirectly through their influence on corruption [9].

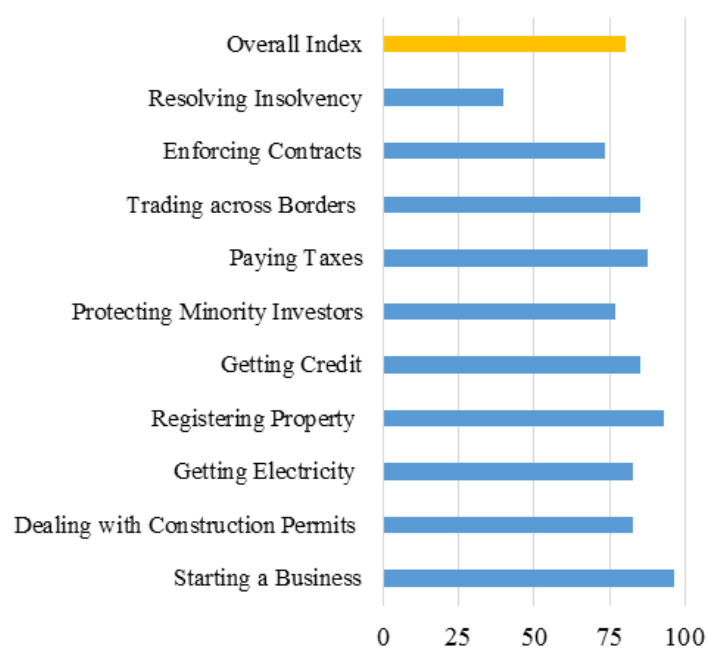

Fig. 1. Doing Business Index for Georgia, 2017 Year.

Characteristics of corruption and factors that affected to do business are different by wealthy and poor countries. So we must compare Georgian data to the countries which have same levels of income. By World Bank classification of countries Georgia is an Upper-middle-income economy (GNI per capita, calculated using the World Bank Atlas method Upper-middle-income economy are between $\$ 4,036$ to $\$ 12,475$ for Upper-middle-income economies; The Word Bank). In the analyze we include upper middle countries on which data are available for both of corruption perception index and all indices of doing business.

37 countries meet selected criteria, these economies are: Albania, Algeria, Azerbaijan, Belarus, Bosnia and Herzegovina, Brazil, Bulgaria, China, Colombia, Costa Rica, Dominica, Dominican Republic, Ecuador, Gabon, Georgia, Guyana, Iran, Jamaica, Lebanon, Malaysia, Maldives, Mauritius, Mexico, Montenegro, Namibia, Panama, Paraguay, Peru, Romania, Russia, Serbia, South Africa, Suriname, Thailand, Turkey and Venezuela.

We use correlation between doing business indices and corruption perception index for country data of 2016 year. Correlation coefficients are given in the table 1. Correlation coefficient between overall doing business index and corruption perception index is positive and important -0.43 .

Also, all correlation coefficient are positive, which means that, countries with better conditions to do business have lower perception of corruption. Highest coefficient have category - "Paying taxes" which is determined by four indicators (number of payment per year, total tax rate, time required to comply taxes and postfilling index). These four components have equal weights in total coefficient calculation ant it's prove that tax rate is not only one important factor that affects business and creates motivation for corruption. High coefficient has category "trading across borders". Barriers which are conflicting to free trade were historically motivation of informal payment at borders from ancient times till today.

TABLE I: CORRELATION COEFFICIENTS BETWEEN CORRUPTION PERCEPTIONS INDEX AND COMPONENTS OF DOING BUSINESS INDEX

\begin{tabular}{|l|c|}
\hline Overall Doing Business Index & $\mathbf{0 . 4 3}$ \\
\hline Paying Taxes & 0.53 \\
\hline Trading across Borders & 0.50 \\
\hline Getting Electricity & 0.34 \\
\hline Protecting Minority Investors & 0.33 \\
\hline Dealing with Construction Permits & 0.29 \\
\hline Getting Credit & 0.26 \\
\hline Resolving Insolvency & 0.24 \\
\hline Starting a Business & 0.23 \\
\hline Enforcing Contracts & 0.10 \\
\hline Registering Property & 0.03 \\
\hline
\end{tabular}

\section{CONCLUSION AND RECCOMENDATIONS}

In Georgia, Institutional development matches successful eliminating of corruption. Data about other upper -middle countries also prove that economies better conditions of doing business have less corrupted economy. To improve institutional framework for continuously elimination of corruption recommendations should be:

Size and structure of government are main determinants for corruption size. Government expenditures are high in Georgia, nearly $30 \%$ of GDP. Also, $15.4 \%$ of employed workers are working in the public sector (National Statistics Office of Georgia, 2016). Besides the size, important topic is organizational structure of the state, which is govern by 19 ministries and increasing numbers of legal entities in Georgia. In many cases different organizations have same functions. Its necessary decrease of bureaucracy and move to small and smart government model for more effectiveness of the state policy-making.

Decrease tax burden - To compare other developed or developing countries, taxes are not high in Georgia. Total tax rate is $16.5 \%$ of commercial profits. (World Bank, 2016). When we speaking about corruption in taxation, tax burden not only determined by tax ratel but also by administrative/transaction costs to pay taxes. As mentioned above, number of taxes was decreased to 6 , but there is still a room for reducing. Sum of taxes on import and taxes on wealth have smallest share (1.2\%) in total government revenues (Ministry of finance of Georgia, 2016) and does not describe by clear economic functions.

Finalize privatization process - 344 government enterprises are still working in Georgia. Most of them have negative income results, $75 \%$ of companies are in weak financial 
conditions (State Audit Office of Georgia, 2015). Besides eliminate corruption, privatization can attract more investments and make them profitable.

In conclusion, economic policy should be concentrated to improve institutional framework which will promote non-corrupted economy, where state policy would suitable to access sustainable economic development rates.

\section{REFERENCES}

[1] S. Rose-Ackerman, "The Economics of Corruption," Journal of Political Economy, Vol. IV, pp. 187-203, February 1975.

[2] S. Rose-Ackerman, "International handbook on the economics of corruption," Multiple Access, Introduction and Overview, Edward Elgar Publishing, Inc., 2006.

[3] R. H. Coase, "The nature of the firm," Economica, Blackwell Publishing, vol. 4, no. 16, pp. 386-405, November 1937.

[4] T. Eggertsson, "Economic behavior and institutions: Principles of neoinstitutional economics," Cambridge University Press, U.K, p. 14, 1990.

[5] D. C. North, Institutions, Institutional Change and Economic Performance, Washington University, St Louis, ch. 1, 4, 5, pp. 3-11, 36-54, 1991.

[6] P. M. Lichtenstein, 1996, "A New-Institutionalist Story about the Transformation of Former Socialist Economies: A Recounting and an Assessment," Journal of Economic Issues, vol. 30, no. 1, pp. 243-265, March 1996.
[7] J. M. Kramer, "Political Corruption in the U. S. S. R.," The Western Political Quarterly, vol. 30, no. 2 pp. 213-224, Jun. 1977.

[8] T. S. Aidt, "Corruption, institutions, and economic development," Oxford Review of Economic Policy, vol. 25, no. 2, pp. 271-291, March 2009.

[9] B. Venard, "Institutions, corruption and sustainable development," Economics Bulletin, vol. 33, no. 4, pp. 2545-2562, October 2013.

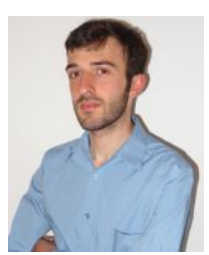

Tsotne Zhghenti was born in Tbilisi, Georgia in November 21. He graduated Ivane Javakhishvili Tbilisi State University from with a bachelor degree of economics in 2013 . He remained at the university and to complete his master study in economics in 2015. Now he is studding on the same university to get $\mathrm{PhD}$ degree. Tsotne Zhghenti has worked in National Statistics Office of Georgia from 2015 to 2016. He have participated several conferences and published articles: "Savings or Foreign investment, the way for economic growth of Georgia" in Proc. Multidisciplinary Academic Conference on Economics, Management and Marketing in Prague, 2014. "Formal and informal monetary institutions in transition - The case of Georgia" in Proc. IAC-MEBM in Vienna, 2016. "Measure Types of Institutions - Georgia and Transition Economies" International Journal of Innovation, Management and Technology (IJIMT).

His current research interests of author are institutionalism and transition economics. 